\title{
Hydrous fluid metasomatism in spinel dunite xenoliths from the Bearpaw Mountains, Montana, USA
}

\author{
John Facer and Hilary Downes \\ School of Earth Sciences, Birkbeck, University of London, Malet Street, London WC1E 7HX, UK
}

The Bearpaw Mountains are situated on the northern margin of the Archean Wyoming craton and form part of an extensive Eocene high-K magmatic province.

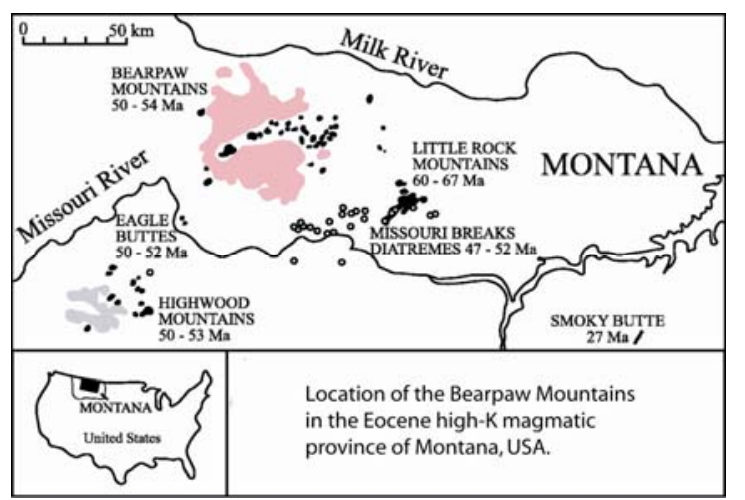

It has been suggested that the magmatism here was triggered by fluids or melts from the subducted Farallon slab interacting with the overlying asthenospheric wedge beneath the Wyoming cratonic keel. It has also been suggested that the low-angled subduction of the Farallon plate resulted in much of the North American mantle lithosphere being hydrated as far east as the Colorado Plateau. Support for this latter hypothesis has come from veins of Al-poor fibrous orthopyroxene with distinctive spherulitic or radial textures found in xenoliths from the Colorado Plateau (Smith et al., 1999). Comparable textures are found in modern sub-arc mantle xenoliths and have been attributed to interaction between olivine and slabderived fluids (e.g., McInnes et al., 2001).

Here we report on a suite of nine Fe-rich spinel dunite xenoliths from the Bearpaw Mountains containing evidence of fluid-rock interaction in the mantle lithosphere of the Wyoming craton. These xenoliths clearly show the breakdown of existing minerals and formation of new metasomatic phases as a result of fluid infiltration. Several samples contain veins of Alpoor fibrous orthopyroxene, sometimes forming spherulitic or radial aggregates, and in at least one xenolith, orthopyroxene was being precipitated at the time when the Eocene eruption occurred. The metasomatic reactions in these xenoliths may, therefore, be related to the contemporaneous subduction of the Farallon slab some $1000 \mathrm{~km}$ inboard of the trench.

\section{Petrography}

The mineralogy of the xenoliths is dominated by olivine $(\geq 96 \%$ except for xenoliths cut by orthopyroxenite veins). Most xenoliths are porphyroclastic in texture and have deformation features as well as textures suggesting grain boundary migration and dynamic recrystallisation. Olivine grain boundaries are surrounded and penetrated by a network of veinlets which connect with small $(0.5-3.0 \mathrm{~mm})$ intergranular pockets. These "reaction pockets" are commonly associated with partially dissolved spinel and (in two xenoliths) partially dissolved clinopyroxenes and/or orthopyroxenes and/or amphiboles. These partially dissolved pyroxenes and amphiboles are referred to (together with the olivine and spinel) as "primary" and designated "Cpx-I", "Opx-I" and "Amp-I" in order to distinguish them from the metasomatic minerals precipitated in the reaction pockets. Dissolution of olivine is less obvious but has clearly occurred around the margins of reaction pockets and in olivine penetrating veinlets. Many spinels show extensive alteration including skeletal and embayed crystal forms and scalloped or ragged margins. The backscattered electron (BSE) image below shows a reaction pocket containing spinel and dissolving Cpx-I.

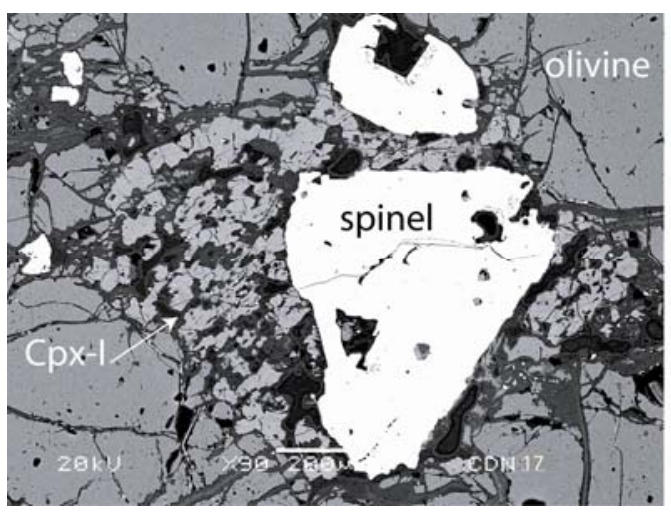

Metasomatic minerals present in reaction pockets include clinopyroxene ("Cpx-II"), orthopyroxene ("Opx-II") and amphibole ("Amp-II"). Chlorite is ubiquitous, filling veinlets and generally forming the matrix within reaction pockets. In some instances, as in the reaction pocket in the BSE image immediately below, Cpx-II, Opx-II and Amp-II are found growing together in apparent equilibrium. 


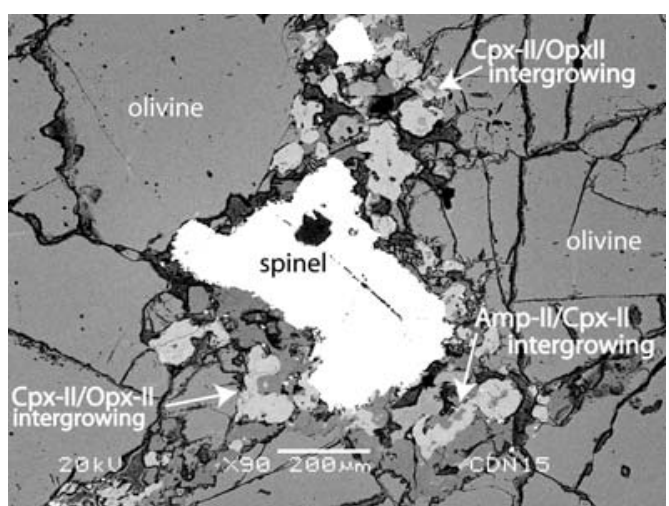

Three of the xenoliths studied contain veins of Opx-II. In one, there are veins up to $2 \mathrm{~mm}$ wide with interspersed nodules at which fibrous orthopyroxene forms spherulitic or radiating aggregates as illustrated in the photomicrograph below.

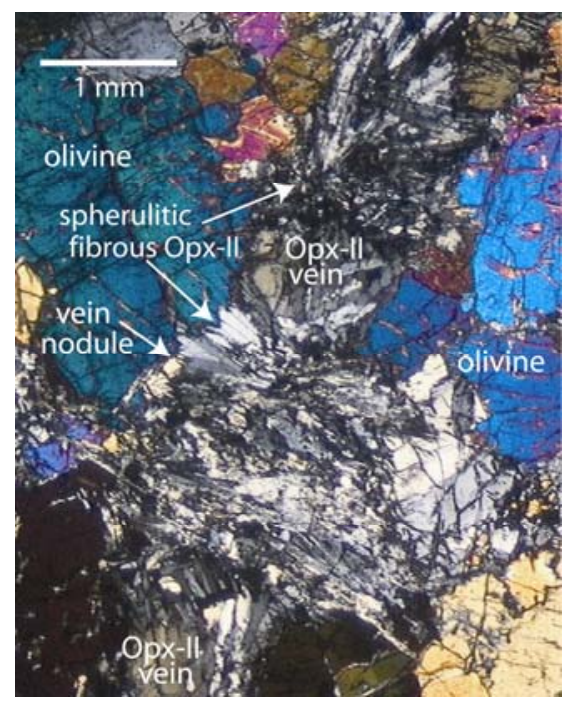

In another xenolith, the veins are made up of a network of small interconnecting veinlets. The following BSE image shows a small section of one of these veinlets.

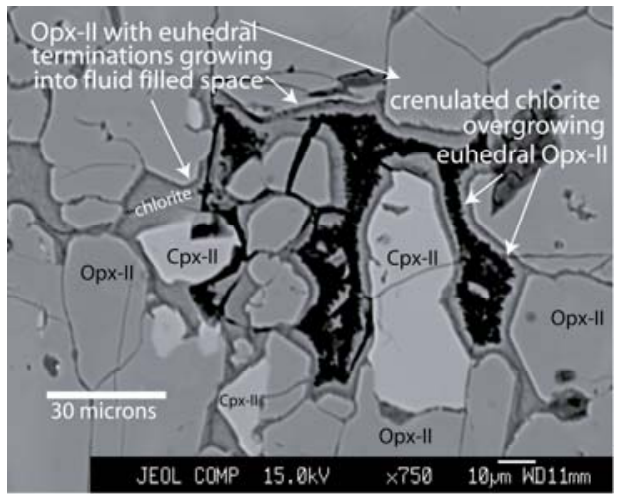

The Opx-II crystals here have euhedral terminations indicating that they grew unrestricted into a fluid filled space. Cpx-II and chlorite are also present and, from its crenulated features overgrowing euhedral Opx-II, it was clearly in the process of being precipitated at the time when the xenolith was erupted. The petrographic evidence is that the Fe-rich dunites have undergone progressive metasomatism as a result of infiltration by a fluid. The fluid penetrated into fine cracks in the olivine and formed films around grain boundaries and, from this and the absence of silicate glass, we infer that it was an aqueous fluid as opposed to a melt.

The xenoliths can be divided into three categories. In Category 1, the fluid has reacted with the primary minerals: olivine, spinel, Cpx-I, Opx-I and Amp-I. At this stage, no new phases have crystallised other than a small amount of calcite. In Category 2, the breakdown reactions with the fluid continue with the disappearence of Cpx-I, Opx-I and Amp-I and the precipitation of new metasomatic phases in the reaction pockets, principally, Cpx-II, Opx-II and Amp-II. Category 3 is similar to Category 2 but contains veins of fibrous Opx-II and has Cpx-II, Opx-II and, sometimes, Amp-II growing in apparent equilibrium.

\section{Geochemistry}

Major element and trace element mineral analyses were obtained at Birkbeck using a Jeol 8100 Superprobe (WDS) and a New Wave Research UP213 LA-ICPMS, respectively. Whole-rock analyses of selected xenoliths were made by XRF at Royal Holloway, University of London and by solution ICP-MS at the University of Montpellier.

Olivine in the xenoliths ranges from $\mathrm{Fo}_{86}$ to $\mathrm{Fo}_{83}$ and has low $\mathrm{NiO}(0.12-0.32$ wt.\%). Spinel is mainly chromite but a Ni-rich (2.3 wt.\% NiO) magnetite is also present. The pyroxenes are diopside and enstatite and the amphibole, pargasite. The xenoliths also contain small disseminated grains: those identified by electron microprobe include magnetite, barium sulphate (baryte) and Fe-Ni sulphide (pentlandite).

Many chomite spinels are compositionally zoned with rims poorer in $\mathrm{Al}$ than the cores. $\mathrm{Al}_{2} \mathrm{O}_{3}$ contents at the rim can be as much as $50 \%$ lower than at the core while $\mathrm{Cr}_{2} \mathrm{O}_{3}$ hardly varies at all. In the pyroxenes and amphibole, the overall trend from Categories 1 to 3 is one of falling $\mathrm{Al}_{2} \mathrm{O}_{3}$ although there is considerable variation within xenoliths and even within the same reaction pocket. This intrasample variation may reflect the proximity of precipitating minerals to dissolving spinel. Chlorite is another mineral which shows marked variations in Al. The chlorite which forms the matrix within most reaction pockets often has vug-like textural features which (in BSE images) have light coloured rims and dark interiors. An electron microprobe traverse across one of these vugs revealed compositonal zoning with the rim being Al-rich and the interior Al-poor. Again, this may reflect the degree of proximity to spinel in the reaction pocket. The chlorite is interpreted as being the result of the precipitation of the residual fluid and its dissolved components when the xenoliths erupted.

Temperatures estimated for six of the xenoliths using the $\mathrm{Ca}$ in orthopyroxene method of Brey \& Köhler 
(1999) were $1042-1078{ }^{\circ} \mathrm{C}$ for orthopyroxene veins and $812-1062{ }^{\circ} \mathrm{C}$ for reaction pockets away from such veins. Oxygen fugacity calculated in accordance with Ballhaus et al. (1991) at these temperatures and an assumed pressure of $2 \mathrm{GPa}$ gave $\Delta\left(f \mathrm{O}_{2}\right)^{\mathrm{FMQ}}$ values ranging from 0.42 to 2.3 . $\mathrm{CDN} 17$ (Category 1) showed the lowest, and CDN 15 (Category 3) the highest, oxygen fugacity values.

The XRF whole-rock analyses show that the xenoliths are very $\mathrm{Al}, \mathrm{Ca}$ and $\mathrm{Ti}$ depleted and very iron-rich. Apart from being iron-rich, they fall generally within the range of compositions of the Bearpaw tectonite xenoliths reported by Downes et al. (2004) which, in turn, overlap the field of cratonic spinel peridotite whole-rock compositions.

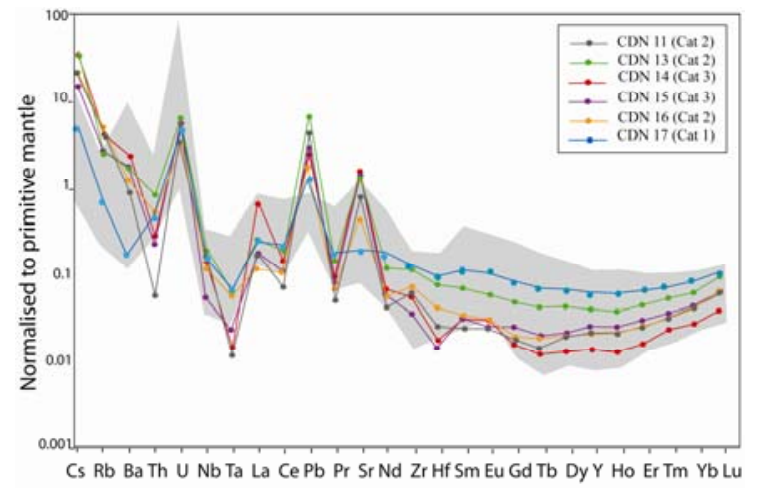

The mantle-normalised whole-rock trace element patterns (above) show strong enrichment in the aqueous fluid mobile elements $\mathrm{Cs}, \mathrm{U}$ and $\mathrm{Pb}$ and in the LILE, $\mathrm{Rb}, \mathrm{Sr}$, and $\mathrm{Ba}$. There are significant troughs at the HFSE, Nb-Ta and Zr-Hf with Ta being exceptionally low, particularly in Category 3 xenoliths. REE are all extremely depleted and show a concave Ushaped pattern with HREE enriched relative to LREE. The Bearpaw tectonite peridotites (grey field) show similar patterns but are more enriched.

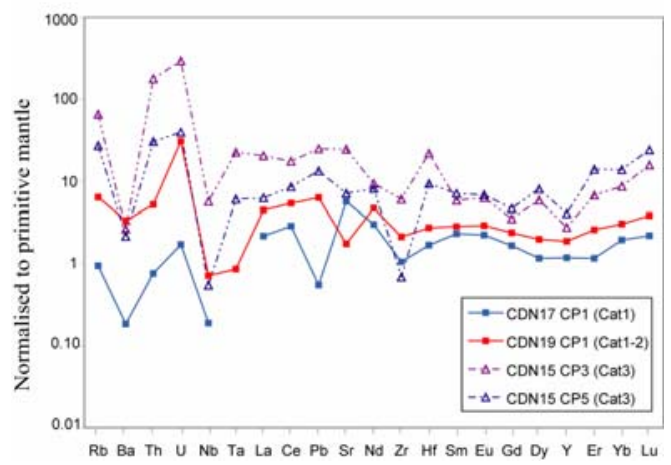

Mantle-normalised trace element patterns for clinopyroxenes are shown in the chart above. The patterns for the Category 1 and transitional Category 1/Category 2 xenoliths (solid lines) show troughs at $\mathrm{Nb}$-Ta (in CDN $17 \mathrm{Ta}$ is actually below the detection level) and Zr-Hf while in the Category 3 xenolith (dashed lines) $\mathrm{Ta}$ and $\mathrm{Hf}$ are both enriched. The MREE to HREE in Categories 1 and 1-2 show a shallow U-shaped pattern but in Category 3 there is more variation with positive anomalies at Eu and Dy and enrichment in $\mathrm{Er}, \mathrm{Yb}$ and $\mathrm{Lu}$. Chondritenormalised REE patterns (not illustrated) for clinopyroxenes from CDN 15 (a Category 3 xenolith) have $(\mathrm{Yb} / \mathrm{Gd}) \mathrm{n}$ ratios averaging 4.3 and $\mathrm{CDN} 14$ (also Category 3) has positive $\mathrm{Eu} / \mathrm{Eu}^{*}$ anomalies for clinopyroxenes of up to 2.5 .

The positive $\mathrm{Eu}$ anomalies may be due to $\mathrm{Eu}^{2+}$ being partitioned into the fluid from metamorphosed plagioclase in the slab. Recent studies (e.g., Condie et al., 2004) have suggested that up to $80 \%$ of HFSE and up to $50 \% \mathrm{Yb}$ occur in phases along grain boundaries and it is possible that the fluid reactions at grain boundaries seen in the dunite xenoliths resulted in a remobilisation of such trace elements, explaining the enrichment in HREE, Ta and Hf in the Category 3 clinopyroxene.

\section{Conclusions}

The petrographic evidence is that the Bearpaw dunite xenoliths have undergone progressive metasomatism as a result of infiltration by an aqueous fluid. The veins of Al-poor orthopyroxene, with radial textures similar to those in modern sub-arc xenoliths, together with the characteristic trace element patterns associated with subduction zones, suggest that the fluid was derived from a subducting slab. The petrographic evidence that the metasomatism was continuing at the time when the xenoliths were erupted in the Eocene suggests that that slab was part of the subducting Farallon plate.

\section{References}

Ballhaus, C., Berry, R.F. \& Green, D.H. (1991). High pressure experimental calibration of the olivineorthopyroxene-spinel oxygen geobarometer: implications for the oxidation state of the upper mantle. Contrib. Mineral. Petrol., 107, 27-40.

Brey, G.P. \& Köhler, T., (1990). Geothermobarometry in four-phase lherzolites: II. new thermobarometers and practical assessment of existing thermobarometers. J.Petrol., 31, 1353-1378.

Condie, K.C., Cox, J., O'Reilly, S.Y., Griffin, W.L. \& Kerrich, R. (2004). Distribution of high field strength and rare earth elements in mantle and lower crustal xenoliths from the southwestern United States: The role of grain boundary phases. Geochim. Cosmochim. Acta 68, 3919-3942. Downes, H., Macdonald, R., Upton, B.G.J., Cox, K.G., Bodinier, J-L., Mason, P.R.D., James, D., Hill, P.G. \& Hearn. B.C. Jr. (2004). Ultramafic Xenoliths from the Bearpaw Mountains, Montana, USA: Evidence for Multiple Metasomatic Events in the Lithospheric Mantle beneath the Wyoming Craton. J. Petrol., 45, 1631-1662.

McInnes, B.I.A., Gregoire, M., Binns, R.A., Herzig, P.M. \& Hannington, M.D. (2001). Hydrous metasomatism of oceanic sub-arc mantle, Lihir, Papua New Guinea: petrology and geochemistry of fluid-metasomatised mantle wedge xenoliths. Earth Planet. Sci. Lett., 188, 169-183.

Smith, D., Riter, J.C.A. \& Mertzman, S.A. (1999). Waterrock interactions, orthopyroxene growth, and Si-enrichment in the mantle: evidence in xenoliths from the Colorado Plateau, southwestern United States. Earth Planet. Sci. Lett., 165, 45-54 